Ambrose, R. \& Molina, M. (2014). Spanish/English bilingual students' comprehension of arithmetic story problem texts. International Journal of Science and Mathematics Education, 12(6), 1469-1496. DOI: 10.1007/s10763-013-9472-2.

\title{
SPANISH/ENGLISH BILINGUAL STUDENTS’ COMPREHENSION OF ARITHMETIC STORY PROBLEM TEXTS
}

\author{
Rebecca Ambrose \& Marta Molina
}

\begin{abstract}
In this paper we explore some of factors that affect bilingual students' comprehension of story problems: vocabulary, syntax, cultural relevance and understanding of the word problem genre. In an effort to determine how these factors interact, we asked 18 Spanish/English bilingual children to retell and solve arithmetic story problems in their first and second language in one-on-one interviews. We found that students attempted to build meaningful representations with coherence among events and actions and manipulated the quantities according to their interpretation. Occasional unfamiliar vocabulary tended not to be an issue. Children made inferences drawing on their personal experiences to make the texts more coherent. It was not so much the surface features of the text including syntax and vocabulary that interfered with children's interpreting them successfully, rather it was the situations and the limited information provided about them that affected comprehension. We conclude with implications for teachers and textbook writers.
\end{abstract}

KEYWORDS: bilingual students, comprehension, language, mathematics, retelling, story problems.

Mathematical story problems present a challenge to students around the world, whether they are presented in the students' first or second language (Verschaffel, Greer, Van Dooren, \& Mukhopadhyay, 2009). This may be due to the contrived nature of story problem texts (Gerofsky, 1996). Students often have a "compulsion to calculate” (Stacey \& MacGregor, 1999), and find key words, numbers, and compute. Difficulties may also be due to students' miscomprehension of story problem texts (Cummins, Kintsch, Reusser \& Weimer, 1988), unfamiliar vocabulary, complex grammar and problem situations that students may have no experience with. Working in their second language can exacerbate the difficulties of solving story problems for bilingual students (Kempert, Saalbach \& Hardy, 2011). Being bilingual may also provide students with advantages in solving story problems (Kempert et al., 2011). Specifically, greater executive 
control (Bialystok, 2009) may promote the selective attention necessary to identify essential information in story problems, and bilingual students' willingness to persist in the face of ambiguity (Marinova-Todd, 2012) may help students deal with terse story problem texts.

Students’ success rates on story problems do not provide insight into how different factors contribute to their responses to story problems. In this paper we present a study in which we explored some of these factors by asking bilingual children to retell and solve arithmetic story problems in their first language (L1) and their second language (L2) in one-on-one interviews based on the question: How do vocabulary, syntax, cultural relevance and understanding of the genre affect young Spanish/English bilingual children's comprehension of story problems? This research question emerged after data collection, and our study design would have been different had we set out to explore this question from the outset of the study. We share our data here along with some speculation about the reasons for our results and some ideas about further research to test our hypotheses.

\section{THEORETICAL FRAMEWORK AND RELEVANT RESEARCH}

Numerous studies have analyzed factors affecting students' success in problem solving. We focus here on the case of arithmetic story problems where only verbal language is used to present information (i.e., no graphical or pictorial representations are included). We attend to factors more relevant to bilingual students, such as language proficiency, cultural relevance of the context, and the particular nature of the story problem genre.

\section{Problem Solving in L1 versus L2}

Many researchers have explored providing bilingual children with story problems in their first (L1) and second language (L2) to determine how the language of the problem text affects their success. Several studies (Bautista, Mitchelmore \& Mulligan, 2009; Bernardo \& Calleja, 2005) indicate that children tend to be more successful when problems are presented in L1 and 
that low performing children are much more sensitive to language (L1 vs. L2) than their higher performing peers. Others have found bilingual children to be equally successful solving story problems in L1 and L2 (Ambrose \& Molina, 2010; Celedón-Pattichis, 2003; Secada, 1991). On the other hand, Oviedo (2005) found that ninth-graders were more successful when ratio and percent problems were presented in L2, the students' language of instruction, than in L1. In her study problems were set in contexts unfamiliar to the students and the "difficulty students had may also be related to features of the problems themselves” (p. 285) rather than whether the problem was administered in L1 or L2. This line of research suggests that the comprehension of story problems depends on many interrelated factors and that translating problems into students' L1 will go only so far in promoting bilingual students' problem comprehension. Moreover these studies, with the exception of Secada's (1991), focused exclusively on students' success rates, providing little insight into how students comprehended texts in either language.

\section{The Role of Language Proficiency and Cultural Background}

Bilingual students vary in their competencies in both L1 and L2 and, not surprisingly, students fluent in both languages perform well on story problems administered in either language (Ní Riordaín \& O’Donoghue, 2009) while their peers with less proficiency in L2 tend to be more sensitive to the language of the problem. Recent research (Kempert et al., 2011) of 8 and 9-yearolds solving story problems in German and Turkish demonstrated that "language proficiency explained as much variance as arithmetic skills did and far more variance than was explained by cognitive ability, SES, and reading comprehension” (p. 556).

Language proficiency also affects students’ performance on standardized tests. Abedi and Lord (2001) found that simplifying the linguistic complexity of story problems improved the performance of English Language Learners (ELLs) while not affecting the performance of 
English Only students. Martiniello (2008) identified partial understanding of polysemous words as sources of difficulties for bilinguals' understanding of problem texts. For example, when responding to the item, “To win a game Tanika must spin an even number on a spinner identical to the one below (p 345)”, a child interpreted the word “one” as a number when it was intended as a pronoun. These studies focused exclusively on problems administered in L2, making it unclear if some of the issues found would also cause difficulties for children in L1.

Martiniello (2008) also found that students’ knowledge of cultural referents in story problems affected their comprehension. For example, students in her study reported being unfamiliar with using coupons at the store and so had difficulty comprehending the phrase “coupon for \$1.00 off”. Oviedo (2005) argued that the unfamiliar situations described in her percentage problems (making concrete, being a key punch operator) were distractors to her students and concluded that there was an interaction between problem contexts and the language of presentation. Celdon-Pattichis (2003) reported that her Hispanic middle school students had difficulty with a story problem about astronomy due to their lack of personal experience with this field. Unfamiliarity with the context described in a problem potentially affects all students but especially those that do not belong to the majority cultural group.

\section{The story problem genre}

Story problems are a particular genre of text (Gerofsky, 1996) written specifically for academic activity. Children have to learn to suspend their disbelief and treat these contrived problem situations as if they were true. They also need to learn that the purpose of reading mathematical story problems differs from that of reading fictional narratives (Weist, 2003). Rather than make inferences about the text to develop a coherent plot line, students must determine the unknown quantity requested in the question statement (Kintsch \& Greeno, 1985).

Several researchers have shown that successful problem solvers do not directly translate 
problems into equations, rather they form intermediary situation models which include information about quantities and actions on the quantities or relationships between quantities (Hegarty, Mayer, \& Monk, 1995). To build the situation model problem solvers use their realworld knowledge and personal experiences to interpret the information found in the text base (Voyer, 2010). This model takes into account non-mathematical information and helps them to construct a problem model (Kintsch \& Greeno, 1985), that is, the mental mathematics representation of the problem that guide the solving process. Students find it easier to understand story problems when the texts include explanations for the actions in the problem (Moreau \& Coquin-Viennot, 2003) and look for causal explanations of actions, states and events (Graesser, Singer \& Trabasso, 1994). Their performance can be hindered by additional information inconsistent with the appropriate situation model (Matarella-Micke \& Bellock, 2010).

Many textbook story problems require making inferences using some shared knowledge about the "the rules of math," that has been called word-problem schemata (Verschaffel et al., 2009). For example, solvers might have to assume that sharing in a problem must be fair and that all elements have to be shared. From their experience in school contexts, students develop math problem schemas that inform them about how to compensate for insufficiencies in the text (De Corte \& Verschaffel, 1985) and learn to make predictions about text organization (i.e. setting, actions, question; as pointed by Gerofsky, 1996) and content (Miller, 2002).

The skill that bilingual students develop in selectively attending to the most salient aspects of language and glossing over less essential elements (Bialystok, 2009) can be either a strength or a hinderance when they face the task of comprehending story problem texts. If students learn to attend to what Voyer (2010) called "solving information" (p. 1075), and ignore context information unnecessary for understanding the quantities and relationship between them, 
they should become successful problem solvers. If their attention is drawn to non-essential features, they may make inappropriate inferences and be led to operate on the quantities in the problem incorrectly. Frequent failure in their attempts to comprehend problem may lead them to disregard the text completely and "select the most familiar arithmetic operation, or the operation most recently discussed in class” (Bautista et al., 2009, p. 740). Classroom norms may also lead to this behavior (Verschaffel et al, 2009).

Comprehending story problems requires a different kind of attention than is required of comprehending narrative texts (Kintsch \& Greeno, 1985), and any classroom discussion about ways to approach the task of reading or understanding story problems may be lost on those bilingual students who have difficulty tracking academic discussions in L2. It remains to be seen when instruction on the specific register of story problems should take place and how it should be done, although understanding strategies recommended for other genres (e.g., looking for important information, liking to prior knowledge, identifying the main features of the text) (Harvey \& Goudvis, 2007) and awareness of how to use them (Paris, Lipson \& Wixon, 1983), might be a good starting point.

\section{The complexity of bilingualism and problem solving}

Given the complexity of bilingualism (Clarkson \& Galbraith,1992) along with the variance in the specific features of the story problems themselves including vocabulary, grammar and context, as well as students' prior experiences with story problems, it follows that attempts to explain students' responses by isolating variables will be unlikely to generalize broadly. We believe that descriptive accounts that capture bilingual students' comprehension of problem texts, and their attempts to solve problems, will provide insight into how these factors interact. Given this complexity, Martiniello (2008) recommended that “more studies using think-aloud protocols 
should be conducted to investigate how ELLs interpret math word problems” (p. 362). With this work we hope to contribute to the body of studies that can illuminate this complexity.

\section{METHOD}

We conducted the research in one school district that served students from a low-income community in Northern California in which $80 \%$ of the students received lunch subsidies, $43 \%$ were designated as ELLs and 35\% of the students were Hispanic. 18 first-grade Hispanic bilingual students who had been identified as either Early Intermediate or Intermediate English speakers by school staff using the California English Language Development test participated in the study. Eleven were boys and seven were girls. They were first- or second-generation Latin American immigrants who had been schooled exclusively in the US. When asked about their use of Spanish and English at home, most reported speaking a combination of both languages with their families and friends but they varied in the frequency of use of each language and the type of person who they used each language with (e.g., siblings, relatives, neighbors). They were from four classrooms of teachers who participated in training in Cognitively Guided Instruction (Carpenter, Fennema, Franke, Levi, \& Empson, 1999), and had experiences solving story problems and sharing strategies in their classrooms. All mathematics instruction was in English and none of the teachers spoke Spanish.

We constructed two equivalent batteries of problems in English and in Spanish (see Table 1). The problems were matched in terms of mathematical structure, with number pairs of similar complexity. The addition and subtraction problems were written to replicate the wordy problems that students sometimes encounter at school, so they included some complex linguistic structures. For the division problems we took into account Abedi and Lord's (2001) findings about the linguistic factors that affected ELLs’ problem solving success and formulated short sentences 
with simple present or past tense verbs and avoided the use of conditionals, subordinate clauses and connectors such as "in order to." We did not use direct translations of the problems because children might remember having solved the problem in the previous session.

\section{INSERT TABLE 1 HERE}

Children were interviewed in the $8^{\text {th }}$ month of the school year on one day with the first author, a native English speaker and on another day with the second author, a native Spanish speaker. We read the problems to the children and asked them to retell them before solving, a technique that has been used by researchers to assess children's comprehension of problems (e.g., Secada, 1991; Verschaffel, 1994). Children had access to paper, pencil and blocks and were encouraged to solve the problems in any way they wanted. While they were solving the problem, we reread the problem to them if they seemed stuck. We also administered the Peabody Picture vocabulary test (PPVT) (Dunn \& Dunn, 1997), a standardized test, to measure students’ receptive vocabulary proficiency in English and in Spanish.

Retellings were coded according to which of the following essential elements were included: numbers, units, action and question (see Table 2). We used three codes for the numbers in the problem: identical, different or missing. We added a fourth code, consistent, for the other elements. Given Hegarty et al.’s (1995) finding that students who focused on essential meanings of problem texts were more successful than those who remembered exact wordings, we differentiated between identical elements and consistent elements. Identical elements had the same wording as in the original problem while consistent elements included different words with a meaning that promoted a situation model congruent with the original text. For example, in the English addition problem, when children used the word “apples” it was coded as identical, and when children used the word "banana”, it was coded as consistent. Inconsistent elements were 
those that could lead children to miscomprehend problem texts. For example, a child used the word "eat" in the retelling of the English addition problem which suggested a different action that could lead the child to assume that he should subtract (instead of adding) to solve the problem (see Table 7). Division problems included an additional element which was essential to successful comprehension: the condition "there were the same number of units in each group." We coded this condition with the codes: identical, consistent or missing. The analysis of the retelling helped us to identify which of the elements of the problem students attended to and, together with their solving strategy, informed us about the students' comprehension of the situation presented in the problem. We also kept track of the non-essential elements that children included in their retellings.

\section{INSERT TABLE 2 HERE}

\section{FINDINGS}

In the addition and subtraction problems, students' rate of successful solutions was high, going from $75 \%$ in the Spanish addition problem to 100\% in the English subtraction problem, and was a first indicator that children developed an adequate situation model. However, only one student properly solved one of the division problems, the English one. We interpret these results taking into account the language proficiency measures of each student presented below. Students' retelling in Spanish are translated mimicking the grammatical components of the sentences. For example, when students’ retellings had an unusual word order (e.g. “¿cuántos *ya* están descansando?” instead of “¿cuántos están ya descansando?”) we similarly changed the order of the words in the corresponding English translation (e.g. "How many are resting *already*?”).

\section{Language Proficiency}

PPVT results (see Table 3) indicated that students' receptive vocabulary ranged from an 
age equivalent of 3 years- 6 months to 7 years-3 months in English, and 2 years-11 months to 8 years-3 months in Spanish. The average of the results of the test of all the students was slightly higher in English than in Spanish (5 years and 7 months vs 5 years and 4 months). The children were between 6 and 7 years old. Eight students performed higher or slightly higher in Spanish; one performed similarly in both languages and nine children did better in English. In addition, only 6 students were able to count to 25 in Spanish while all counted to 100 in English. These findings led us to conclude that the term bilingual was much more appropriate for these children than ELLs because of the range of proficiencies in each language.

\section{INSERT TABLE 3 HERE}

\section{Subtraction Problems}

Of all of the problems that we gave, children had the most success retelling and solving the English version of the subtraction problem. Children did not provide word-for-word retellings (see Table 4) paraphrasing the text instead. For example, L used the phrase "went away" for the action word "leave", and he stated the question in a shorter fashion. Many children included specific words not essential to solving the problem. For example, $82 \%$ of the children included “panda” in their story, and 64\% noted that the panda was “giant” or "big”.

\section{INSERT TABLE 4 HERE}

Table 5 illustrates that the majority of the students included the appropriate (identical or consistent) units (89\%) and an appropriate action (83\%). A high percentage of the children (67\%) left out the question from their retelling. While some different numbers appeared in the retellings, after hearing the problem again all children corrected this misapprehension when solving the problem. As shown in Table 5 some retellings included grammatical mistakes. 
Results for the Spanish subtraction problem were similar but indicated that children were unfamiliar with the units in this problem "leones marinos" (sea lions), although none asked for clarification about the phrase. Children handled the ambiguity of this phrase in different ways. $28 \%$ of the retellings included "leones" (see U and F in Table 6), and 17\% of the retellings included the word "marinos" (see M in Table 6) that we interpret and translate as "sea animals" because this word acts as an adjective that refers to the dropped word "leones" (lions). 17\% of the retellings did not have an action (see F in Table 6). U's retelling (see Table 6) shows how his interpretation of the text has internal coherence achieved by adding additional elements not in the original problem. He was one of the children whose English was more advanced than his Spanish (see Table 3). His retelling and that of three others included words in English (see U in Table 6). Students also made some grammatical mistakes, mostly when paraphrasing the question, due to word misplacement and incorrect verb tenses indicating their limited Spanish proficiency. 


\section{Addition problems}

The English addition problem involved a more complicated situation than the subtraction problems because the units (apples and pears) and the actors (zookeeper and monkeys) were distinct, unlike the subtraction problem in which the units (people) were also the actors. Only two children included all four entities—zookeeper, monkeys, pears and apples—in their retelling of the problem (see $\mathrm{C}$ in Table 7). One of the children retold the problem without including the actors and many other details of the problem (see $\mathrm{O}$ in Table 7). This simple retelling was the exception. Most children included non-essential details in their retellings as in the subtraction problems. Half of the children included at least one time element in their retell, and half of the retellings included the word "monkey."

\section{INSERT TABLE 7 HERE}

Some of the vocabulary in this problem was unfamiliar to the children, specifically "zookeeper" and "pears". 33\% of the retellings included the word "zookeeper" while 22\% did not specify the actor who was giving fruit and some referred to a "zooman" and "zoo guy." Only one child seemed to get stuck because she did not know the word, referring to a "Susie Bird" who gave something. $11 \%$ of the retellings indicated difficulty with the word "pear" (e.g., see U in Table 7).

Table 8 shows that most children (83\%) included the identical action word "give". One retelling (see U in Table 7) included the action of eating which we considered to be inconsistent with the problem statement because it could lead the child to assume that he should subtract to solve the problem. $61 \%$ of the retellings included two quantities of fruit, but $39 \%$ did not include both types of fruit specified in the problem. $11 \%$ specified bananas and $17 \%$ included only one type of fruit. While the children's retellings may have been missing many elements, only one 
child (U) retold the story in a way that indicated miscomprehension of the problem text.

\section{INSERT TABLE 8 HERE}

Retellings of the Spanish addition problem were similar to those of the English addition problem. Children tended to include an identical action word but did not include the identical units (see Table 8). 56\% of the retellings did not include a distinction between the different flowers picked (see M in Table 9) while 22\% referred to flowers and either "margaritas” or “rosas” (see J in Table 9) which we considered "consistent units".

\section{INSERT TABLE 9 HERE}

$56 \%$ of the retellings distinguish between two different times in the story with expressions such as "luego" (later) or “mañana” (morning) (see K in Table 9) and 28\% referred to two different settings (the park and the house/garden)) (see M in Table 9). When students included the question of the problem, 4 out of 5 gave a shorter version of it which we considered to be consistent in meaning to the original one. These questions asked about the total amount although they were formulated incorrectly (see Table 9).

\section{Division Problems}

Division problems proved to be much more difficult for children to retell in both languages. In the English problem retellings tended to include appropriate units and actions (see Table 10 \& Table 11), but none included the condition.

\section{INSERT TABLES 10 \& 11 HERE}

$50 \%$ of the children missed elements in their retelling but did not have different elements (e.g. see $\mathrm{R} \& \mathrm{O}$ in Table 10). When solving the problem these children modeled the situation according to what they recalled. For example, $\mathrm{O}$ drew four tables and reported that 8 children sat at the first table, 10 at the second, 5 at the third and 6 at the last one. Another child drew 2 tables and 6 children sitting at each one. 44\% of the children provided retellings indicating that they 
comprehended the situation differently than we had intended. L's retelling (see table 10) illustrates an interpretation that the tables had numbers on them. Another child noted that the chairs were numbered, and another said "4 people had the same number”. These retellings suggest children tried to incorporate the word "number" into their model of the situation and considered it to be an object rather than the cardinality of the group of children at each table. $22 \%$ of the children had the misapprehension that the number of children at each table was given in the problem (e.g., see F in Table 10). When asked what the answer was, one of these children said "12, there are 12 people at each table". She responded without doing any work and without hesitation. While children's solution strategies tended to be aligned with their retelling of the problem, this was not always the case. $22 \%$ of the children added 12 and 4 on their fingers. Another found the difference between 12 and 4 using blocks, and another crossed out 3 of 12 circles. These strategies showed children attending to the numbers in the problem rather than the text.

Several children's comments while solving this problem made it clear that it evoked their personal schemas for birthday parties an spoke about eating cake and ice cream. 39\% of the retellings included the non-essential word "party". One said "If they were friends they would sit next to a friend, but if there were no more chairs, they could sit at a different table”. Another imagined moving to the tables and said "if you run you might get hurt". These vicarious thoughts were not focused on insuring that there was the same number of children at each table, but instead on children's own actions as party-goers.

The Spanish division problem was not set in a context that had as many connotations for the children as the English division problem. Even so, most children did not interpret the story problem text in the way we intended (see Table 12). As in the English division problem, in some 
retellings children included some problem elements while leaving out others (e.g. see I in Table 12). The children's solution strategies demonstrated that many did not make the inference that Mrs. Gomez was distributing all of her 15 cakes to the three boxes. Note that the problem does not clearly specify that all cakes belong in one of the three boxes. One child drew 3 boxes and put 3 circles in the first and second boxes and 9 circles in the last one. Another child drew three boxes and had15 blocks for the cakes and said “it can’t fit them all”. Even though the interviewer clarified that the boxes were large, he persisted in interpreting the question to be how many of the cakes can fit in the boxes? Another child made 3 sets of 3 blocks and noted that there were 6 left over. All of these models are reasonable for the situation described in the text and show that the children manipulated the quantities according to their interpretation of it.

\section{INSERT TABLE 12 HERE}

Two of the children attended to the condition that the same number of cakes belonged in each box and solved the problem by trying to equally distribute all 15 cakes but keeping track of all of the quantities in the problem presented a challenge for both of them. Another pair of children made the inference that all of the cakes would be distributed but did not consider the condition that the same number of cakes was in each box. Y's retelling (see table 12) illustrates that some children had difficulty with the wording of the condition. Similarly to the student's difficulties with the word “number” in the English Division Problem, three children thought of "número" (number) as a physical object rather than as the cardinality of the cakes in the boxes. Only two children solved the Spanish division problem in a way that was inconsistent with their retelling: both added 15 and 3. With the exception of these two children, the children's retellings and approaches showed that they developed situation models of the problem using as much of the information from the problem as they could recall, and that they manipulated the quantities 
according to those models. Many children did not exhaustively and/or equally distribute the cakes. In the children's experience putting things in boxes, the number of items that goes in the box is usually determined by the size of the box and cakes are usually packaged one per box, as was reflected in two children's work.

\section{DISCUSSION}

Here we discuss how the previous results help us to explain how vocabulary, syntax, cultural relevance and understanding of the genre affect bilingual students' problem solving.

\section{Text comprehension}

Children in our sample did not retell the story problems word-for word. Rather their retellings in both English and Spanish indicate that our bilingual students processed story problems similarly to the way children process narrative texts by attempting to build meaningful representations with coherence among events and actions (Graesser et al. 1994). Even though sometimes they made grammatical errors, the combination of students' retelling and solving strategies indicated understanding of the problem story. This result supports Kintsch’s (1986) argument that memory for a text (and so retelling of a text) depends more on the students' mental model of the situation/problem rather than on remembering the original wording of the text. In our study retellings often included non-essential elements and at times children introduced additional elements showing that children sought coherence by making inferences (McNamara, Kintsch, Songer \& Kintsch, 1996).

Children's attention to the action in the story problem texts is consistent with narrative text comprehension in that "comprehenders are particularly sensitive to actions and events" (Graesser et al, 1994, p. 379). The actions described in the narrative were not always the actions associated with the mathematics operation necessary to solve the problem. For example, when retelling the English division problem children included the action of sitting (in chairs at tables). 
Unfortunately attention to this action was not sufficient to successfully solve the problem. In the addition and subtraction problems in both languages children tended to duplicate the actions of getting out of line, leaving the rock, giving fruit and picking flowers, and successfully solved the problems. We interpret children's attention to the actions in the division problems as a positive result because even though they could not mathematize this situation, our young bilingual students engaged in comprehending problem texts in both L1 and L2. This is in contrast to older children who focus primarily on the numbers in a problem (Verschaffel et al, 2009).

The one element that tended to be missing from all retells was the question. The few questions included in the retellings tended to include grammatical errors in the Spanish retellings and were similar to the standard question "How many are there?” in the case of the English retellings. The latter suggests that students have memorized it from hearing it in class. Children's inattention to the questions could be due to their language development. Question formation has been used by linguists as an indicator of English language acquisition because the syntax of questions is quite distinct from that of declarative sentences. Dyson (2008) asserted that there are six stages of development in question generation, and only in the advanced stages are speakers able to generate questions like those in our story problems with question signifiers at the beginning and inversions in word order, as in, "How many pears and apples did the monkey get that day?” Our bilinguals may not have included questions in their retellings because producing questions like those in mathematics problems is particularly difficult for them as it demands linguistic sophistication that they may have not yet attained. It is also possible that they do not yet recognize the question as a specific requirement of the genre of story problems.

\section{Role of vocabulary}

In either language, vocabulary did not prove to be an obstacle to children' comprehension, although some of the words in the problems were unfamiliar to them. In both the "leones 
marinos” problem and the "zookeeper” problem, the children persisted in retelling and solving the problems even when they could not recall particular words from the problem texts. Since the children knew the vast majority of the vocabulary in the problems, these lexical gaps were not an issue in comprehending the problem text. We believe that being bilingual promoted children’s abilities to persist with these problems. Having extensive experience dealing with ambiguity bilinguals become quite adept at inferring the meaning of words from context clues and taking best guesses at the meanings of unfamiliar words (Marinova-Todd, 2012). This suggests that vocabulary is not necessarily an obstacle to comprehending story problem texts for bilingual children, even though their vocabularies in L1 and L2 tend to be smaller than the vocabularies of their monolingual peers (Marinova-Todd, 2012). Inferring the meaning of words works well when readers know about $90 \%$ of the words in the text (Nagy \& Scott, 2000) and when readers can monitor their comprehension to insure that their inference makes sense. Our data suggest that our bilingual students were actively engaged in meaning making and so occasional unfamiliar vocabulary tended not to be an issue for them.

The only vocabulary issue that could have interfered with children's comprehension was the word "number" in the condition of the division problems. In both languages, some children included this word in their retelling as a signifier: "the numbers on the table" or "the number in the cake”. One child did so in both languages. Although most children were not distracted by the word "number", the observed difficulty may be caused by the polysemy of this term. Polysemous words as this one have been identified (Martiniello, 2008), as a challenge that bilingual students face in L1 and L2. It is unknown if they also pose difficulties for monolingual children, nevertheless, since its use in this context is part of the mathematics register, all students would benefit from specific attention to such words in their classrooms (Schlepegrell, 2004). 
In relation to vocabulary, we have also observed a lack of knowledge of number names in Spanish even in students with a higher level of Spanish than English in terms of their PPVT results. This suggests a lack of previous mathematical experiences in Spanish and, together with the success rate results, do not support recommendations of presenting problems to bilingual students in L1 as a way of supporting their problem solving learning. In the case of students with previous schooling in L1 or out-of-school mathematical experience, the use of L1 in problem solving may help them access their mathematical schemas (Moschkovich, 2005) but for students with limited or lack of mathematical experience in L1, it may not make a difference.

\section{The case of division problems}

We were initially surprised by children's difficulties retelling the division problems. The mathematical complexity of these situations as well as their limited experience with this problem type probably contributed to children's difficulties recalling and solving those problems. While the wording of the division problems was fairly simple, the units in these problems differed from those in the other problems. The problems contained two different extensive units (e.g., children and tables) and children needed to find a third intensive unit (e.g., children per table). Children also had to consider the condition that groups were all the same size. Recalling all of this is more demanding than recalling addition and subtraction situations in which there are only extensive units and no special condition.

Students had difficulties understanding the part of the problem stating the condition. Even though we tried to keep the linguistic complexity of the division problems to a minimum when designing the problems, we found a need for the academic phrase, "every table has the same number of children” which none of the children could recall. In this case it is unclear whether it is the grammar of the sentence, the specific word "number" or their limited experience working with same-sized groups that interfered with children's understanding. Moreover the 
situations in the division problems did not draw children's attention to the need for equal sized groups. We consider that these problems were not coherent for the children because the texts did not include explanations for why the partitioning was taking place nor did it align with the personal experiences of the children (e.g., the number of children in a table is usually not an issue in parties). Researchers have found that the more coherent a text is, the more successful readers are in comprehending, as well as in recalling it (McNamara et al., 1996). Our division problems, written in the genre of typical school story problems (Gerofsky, 1996), were brief and concise. Children did as all good comprehenders do when interpreting texts, and drew on their personal experiences to make the texts more coherent by imagining themselves at a party and visualizing putting cakes into boxes. Unfortunately, children's schemas for these situations drew their attention away from equal partitioning. Our data led us to conclude that it was not so much the surface features of the text including syntax and vocabulary that interfered with children's interpreting them successfully, rather it was the situations and the limited information provided about them.

Most of the time children did attend to the problem text and attempted to model the situation as they understood it. This was particularly apparent in the case of the Spanish division problem in which all but two of the children modeled putting cakes into boxes in some fashion. We found children's tendency to make sense of the problem texts an encouraging result, showing that this group of bilingual students had not yet adopted the non-realistic perspective common among school children around the world (Verschaffel et al., 2009). This result is especially remarkable considering that these students were not receiving any special support in their mother tongue in regular instruction.

\section{IMPLICATIONS}


Being bilingual provides children with more practice at selective attention (Bialystok, 2009) and handling ambiguity (Marinova-Todd, 2012). This can serve as an asset when dealing with story problems as was the case for the Spanish subtraction problem about leones marinos. Children inferred that leones marinos were some kind of animal and zeroed in on the most critical part of the text, that some of these animals went into the water. In both the addition problems, many children replaced units in their retellings, specifying that the zookeeper gave bananas instead of pears, or glossed over the two distinct types of flowers picked and focused on the action of joining sets. Further, in both addition problems, children tended to include the identical action words in their retellings suggesting that they selected to attend to this critical element.

In the case of the English division problem, selective attention might have drawn the children to focus on the setting of the problem (party). Their comfort with ambiguity led many to gloss over the part about the "same number of children sat at each table". While they did attend to the action in both division problems, the action words in the text (sitting and putting cakes in boxes) did not lead them to model equal partitioning. Division problems seem to demand a higher language proficiency. Even though we avoided the use of some academic expressions such as "in each table/box", the statement of the condition was difficult to understand for the students. Attending to sentences like that in teaching might be necessary for students to understand these situations.

Bilingual children's selective attention and comfort with ambiguity have implications for mathematics educators. Authors of story problems, especially problems for high stakes tests, should pilot problems with bilingual students to insure that the content of the text does not have distractors that might disproportionally affect bilingual students. Story problems should align 
with the common experience of children, considering their tendency to imagine themselves in situation described in texts when working on problems (Barwell, 2005). Teachers might help bilingual students develop awareness of their tendencies toward selective attention and guessing so that students can engage in these processes judiciously. Further research is needed to determine at what time children can begin to develop this kind of metacognition.

Early in bilingual children's schooling, teachers should use problems that are as coherent as possible so that children persist in trying to understand the situations described in the problems rather than develop a compulsion to calculate (Stacey \& MacGregor, 1999). This might mean that problem texts are longer than those typically found in texts, so that the actions in the problems are explained. For example, explaining why children at a party had to sit at separate tables might have helped our students to comprehend the English division situation and help them to selectively attend to partitioning the children equally. Interpreting the actions in a text from the perspective of the character seems to be a natural response (Rall \& Harris, 2000), which also should be taken into account when writing story problems. For example, in the division story problem imagining oneself finding a spot a table did not require one to partition objects while picking two sets of flowers did support the idea of joining the two sets.

Eventually children need to learn that story problems are a distinct text genre (Gerofsky, 1996) requiring a different kind of attention than narrative texts. Schleppegrell (2004) has emphasized that too often specific academic registers are not explicitly taught to students much to the detriment of ELLs. Further research is necessary to determine at what age children can begin to identify story problem texts and the features that distinguish them from other types of texts, and whether bilingual children's selective attention helps them to learn this distinction. We hope that recognizing these tendencies in bilingual children will help teachers to appreciate the 
assets that they bring to the classroom and build on them.

\section{Acknowledgements}

The study was partially financed by the Spanish program for young researchers named José Castillejo within the Spanish national research plan of Scientific Research, Development and Innovation 2008-2011 and by ITQ 07-413, an Improving Teacher Quality grant administered by the California Post-Secondary Commission.

\section{References}

Abedi, J., \& Lord, C. (2001). The language factor in mathematics. Applied Measurement in Education, 14, 219-234.

Ambrose, R. \& Molina, M. (2010). First-grade Latino English-language learners’ performance on story problems in English versus Spanish. Canadian Journal of Science, Mathematics, and Technology Education, 10(4), 356-369.

Barwell R. (2005). Working on arithmetic word problems when English is an additional language. British Educational Research Journal, 31(3), 329-348.

Bautista, D., Mitchelmore, M., \& Mulligan, J. (2009). Factors influencing Filipino children’s solutions to addition and subtraction problems. Educational Psychology: An International Journal of Experimental Educational Psychology, 29(6), 729-745.

Bernardo, A. B. I., \& Calleja, M. O. (2005). The effects of stating problems in bilingual students' first and second languages on solving mathematics word problems. The Journal of Genetic Psychology, 166, 117-128.

Bialystok, E. (2009). Bilingualism: The good, the bad and the indifferent. Bilingualism: Language and Cognition, 12, 3-11. doi:10.1017/ S1366728908003477.

Carpenter, T. P., Fennema, E., Franke, M., Levi, L., \& Empson, S. B. (1999). Children’s mathematics: Cognitively Guided Instruction. Heinemann: Portsmouth, NH.

Celedón-Pattichis, S. (2003). Constructing meaning: Think-aloud protocols of ELLs on English 
and Spanish word problems. Educators for Urban Minorities, 2(2), 74-90.

Clarkson, P. C., \& Galbraith, P. (1992). Bilingualism and mathematics learning: Another perspective. Journal for Research in Mathematics Education, 23(1), 34-44.

Cummins, D. D., Kintsch, W., Reusser, K., \& Weimer, R. (1988). The role of understanding in solving word problems. Cognitive Psychology, 20, 405-438.

De Corte, E., \& Verschaffel, L. (1985). Beginning first graders' initial representation of arithmetic word problems. Journal of Mathematical Behavior, 4, 3-21.

Dunn, L. M., \& Dunn, L. M. (1997). Peabody picture vocabulary test (3rd ed.). Circle Pines, MN: American Guidance Service.

Dyson, B. (2008). What we can learn from questions: ESL question development and its implications for language assessment. Prospect, 23(1), 16-27.

Gerofsky, S. (1996). A linguistic and narrative view of word problems in mathematics education. For the Learning of Mathematics, 16(2), 36-45.

Graesser, A. C., Singer, M., \& Trabasso, T. (1994). Constructing inferences during narrative text comprehension. Psychological Review, 101(3), 371-395.

Harwey S. \& Goudvis, A. (2001). Strategies that work. Teaching comprehension for understanding and engagement. Portland, Maine: Stenhouse.

Hegarty, M., Mayer, R. E., \& Monk, C. A. (1995). Comprehension of arithmetic word problems: A comparison of successful and unsuccessful problem solvers. Journal of Educational Psychology, 87(1), 18-32.

Kempert, S., Saalbach, H., \& Hardy, I. (2011). Cognitive benefits and costs of bilingualism in elementary school students: The case of mathematical word problems. Journal of Educational Psychology, 103(3), 547-561. 
Kintsch, W. (1986). Learning from text. Cognition and Instruction 3(2), 87-108.

Kintsch, W., \& Greeno, J. (1985). Understanding and solving word arithmetic problems. Psychological Review, 92(1), 109-129.

Marinova-Todd, S. (2012). “Corplum is a core from a plum”: The advantage of bilingual children in the analysis of word meaning from verbal context. Bilingualism: Language and Cognition, 15, 117-127.

Martiniello, M. (2008). Language and the performance of English-language learners in math word problems. Harvard Educational Review, 78(2), 333-368.

Matarella-Micke, A., \& Bellock, S. (2010). Situating math word problems: The story matters. Psychonomic Bulletin, 17(1), 106-111. doi: 10.3758/PBR.17.1.106

McNamara, D., Kintsch, E, Songer, N., \& Kintsch, W. (1996). Are good texts always better? Interactions of text coherence, background knowledge and levels of understanding in learning from text. Cognition and Instruction, 14(1), 1-43.

Miller, D. (2002). Reading with meaning: Teaching comprehension in the Primary Grades. Portland, ME: Stenhouse.

Moreau, S., \& Coquin-Viennot, D. (2003). Comprehension of arithmetic word problems by fifthgrade pupils: Representations and selection of information. British Journal of Educational Psychology, 73, 109-121.

Moschkovich, J. (2005). Using two languages when learning mathematics. Educational Studies in Mathematics, 64, 121-144.

Nagy, W., \& Scott, J. (2000). Vocabulary processes. In M. Kamil, P. Mosenthal, P. Pearson \& R. Barr (Eds.), Handbook of reading research (Vol. 3, pp. 269-284). Mahwah, NJ: Erlbaum.

Ní Ríordáin, M. \& O’ Donoghue, J. (2009). The relationship between performance on 
mathematical word problems and language proficiency for students learning through the medium of Irish. Educational Studies in Mathematics, 71(1), 43-64.

Oviedo, G.C.B. (2005). Comprehending algebra word problems in the first and second languages. In J. Cohen, K. McAlister, K. Rolstad \& J. MacSwan (Eds.), ISB4: Proceedings of the $4^{\text {th }}$ International Symposium of Bilingualism (pp. 267-295). Somerville, MA: Cascadilla Press.

Paris, S. G., Lipson, M. Y. \& Wixon, K. k. (1983). Becoming a strategic reader. Contemporary Educational Psychology, 8, 293-316.

Rall, J. \& Harris, P. L. (2000). In Cinderella's slippers? Story comprehension from the protagonist's point of view. Developmental Psychology, 36(2), 202-208.

Schleppegrell, M. (2004). The language of schooling: A functional linguistics perspective. Mahwah, NJ: Erlbaum.

Secada, W. G. (1991). Degree of bilingualism and arithmetic problem solving in Hispanic first graders. The Elementary School Journal, 92(2), 213-231.

Stacey, K., \& MacGregor M. (1999). Learning the algebraic method of solving problems. Journal of Mathematical Behavior, 18, 149-167.

Verschaffel, L. (1994). Using retelling data to study elementary school children’s representations and solutions of compare problems. Journal for Research in Mathematics Education, 25, 141-165.

Verschaffel, L., Greer, B., Van Dooren, W. \& Mukhopadhyay, S. (2009). Words and worlds: Modeling verbal descriptions of situations. Rotterdan, The Netherlands: Sense Publishers. Voyer, D. (2010). Performance in mathematical problem solving as a function of comprehension and arithmetic skills. International Journal of Science and Mathematics Education, 9(5), 1073-1092. doi: 10.1007/s10763-010-9239-y

Weist, L. (2003). Comprehension of mathematical text. Philosophy of Mathematics Education 
Journal, 17. Retrieved Aug. 29, 2012, from http://people.exeter.ac.uk/PErnest/pome17/lwiest.htm.

Table 1. Story Problems Used for Retellings

\begin{tabular}{|c|c|c|c|}
\hline Problem type & English problems & Spanish problems & $\begin{array}{c}\text { Translation of Spanish } \\
\text { problems }\end{array}$ \\
\hline $\begin{array}{l}\text { Subtraction } \\
\text { (Separate Result } \\
\text { Unknown) }\end{array}$ & $\begin{array}{l}16 \text { people are waiting in line } \\
\text { to see the giant panda. } 7 \\
\text { people leave. How many } \\
\text { people are still waiting in } \\
\text { line to see the giant panda? }\end{array}$ & $\begin{array}{l}14 \text { leones marinos estaban } \\
\text { descansando en una roca. } 6 \text { se } \\
\text { metieron al agua. ¿Cuántos } \\
\text { leones marinos quedaron en la } \\
\text { roca? }\end{array}$ & $\begin{array}{l}14 \text { sea lions were resting on a } \\
\text { rock. } 6 \text { went into the water. How } \\
\text { many sea lions were still on the } \\
\text { rock? }\end{array}$ \\
\hline $\begin{array}{l}\text { Addition (Part- } \\
\text { part-whole, } \\
\text { Whole } \\
\text { Unknown) }\end{array}$ & $\begin{array}{l}\text { In the morning a zoo keeper } \\
\text { gave } 8 \text { pears to the } \\
\text { monkeys. At night he gave } \\
\text { them } 5 \text { apples. How many } \\
\text { pears and apples did the } \\
\text { monkeys get that day? }\end{array}$ & $\begin{array}{l}\text { Ayer por la mañana María } \\
\text { agarró } 9 \text { rosas en el parque. } \\
\text { Por la tarde agarró } 5 \\
\text { margaritas en el jardín de su } \\
\text { casa. ¿Cuántas rosas y } \\
\text { margaritas agarró ayer María? }\end{array}$ & $\begin{array}{l}\text { Yesterday morning Maria picked } \\
9 \text { roses in the park. In the } \\
\text { afternoon she picked } 5 \text { daisies in } \\
\text { the garden of her house. How } \\
\text { many roses and daisies did } \\
\text { Maria pick yesterday? }\end{array}$ \\
\hline $\begin{array}{l}\text { Partitive } \\
\text { Division } \\
\text { (quotient } \\
\text { unknown, no } \\
\text { remainder) }\end{array}$ & $\begin{array}{l}\text { There were } 12 \text { children at } \\
\text { the party. They sat at } 4 \\
\text { tables. Every table had the } \\
\text { same number of children. } \\
\text { How many children sat at } \\
\text { each table? }\end{array}$ & $\begin{array}{l}\text { La Señora Gómez tenía12 } \\
\text { pasteles. Los puso en } 3 \text { cajas. } \\
\text { Puso el mismo número de } \\
\text { pasteles en cada caja. } \\
\text { ¿Cuántos pasteles puso en } \\
\text { cada caja? }\end{array}$ & $\begin{array}{l}\text { Mrs. Gomez had } 12 \text { cakes. She } \\
\text { put them in } 3 \text { boxes. She put the } \\
\text { same number of cakes in each } \\
\text { box. How many cakes did she } \\
\text { put in each box? }\end{array}$ \\
\hline
\end{tabular}

Table 2. Elements of coding rubric for each problem

\begin{tabular}{|c|c|c|c|c|c|c|}
\hline \multirow[b]{3}{*}{ Element } & \multicolumn{6}{|c|}{ Problems } \\
\hline & \multicolumn{2}{|c|}{ Subtraction } & \multicolumn{2}{|c|}{ Addition } & \multicolumn{2}{|c|}{ Division } \\
\hline & English & Spanish & English & Spanish & English & Spanish \\
\hline Numbers & 16,7 & 14,6 & 8,5 & 9,5 & 12,4 & 12,3 \\
\hline Units & People & $\begin{array}{l}\text { leones marinos } \\
\text { sea lions }\end{array}$ & pears, apples & rosas, margaritas & $\begin{array}{l}\text { children, } \\
\text { tables }\end{array}$ & $\begin{array}{l}\text { pasteles, cajas, } \\
\text { cakes, boxes }\end{array}$ \\
\hline Action & Leave & $\begin{array}{l}\text { se metieron } \\
\text { went into }\end{array}$ & Gave & $\begin{array}{l}\text { Agarró } \\
\text { picked }\end{array}$ & sat & $\begin{array}{l}\text { puso } \\
\text { Put }\end{array}$ \\
\hline Question & $\begin{array}{l}\text { How many } \\
\text { people are } \\
\text { still waiting } \\
\text { to see the } \\
\text { giant panda? }\end{array}$ & $\begin{array}{l}\text { ¿Cuántos leones } \\
\text { marinos } \\
\text { quedaron en la } \\
\text { roca? } \\
\text { How many sea } \\
\text { lions remained } \\
\text { on the rock? }\end{array}$ & $\begin{array}{l}\text { How many } \\
\text { pears and } \\
\text { apples did } \\
\text { the monkey } \\
\text { get that day? }\end{array}$ & $\begin{array}{l}\text { ¿Cuántas rosas y } \\
\text { margaritas agarró } \\
\text { ayer María? } \\
\text { How many roses } \\
\text { and daisies did } \\
\text { Maria pick } \\
\text { yesterday? }\end{array}$ & $\begin{array}{l}\text { How many } \\
\text { children sat } \\
\text { at each table? }\end{array}$ & $\begin{array}{l}\text { ¿Cuántos } \\
\text { pasteles puso } \\
\text { en cada caja? } \\
\text { How many } \\
\text { cakes did she } \\
\text { put in each } \\
\text { box? }\end{array}$ \\
\hline
\end{tabular}

Table 3. Children's Receptive Vocabulary

\begin{tabular}{|c|c|c|c|c|c|c|c|}
\hline \multirow[t]{2}{*}{$\begin{array}{l}\text { Child's } \\
\text { initial }\end{array}$} & \multicolumn{2}{|c|}{$\begin{array}{c}\text { Receptive } \\
\text { Vocabulary Age- } \\
\text { equivalent }\end{array}$} & \multirow[t]{2}{*}{$\begin{array}{l}\text { Count to } \\
25 \text { in } \\
\text { Spanish }\end{array}$} & \multirow[t]{2}{*}{$\begin{array}{l}\text { Child's } \\
\text { initial }\end{array}$} & \multicolumn{2}{|c|}{$\begin{array}{l}\text { Receptive Vocabulary } \\
\text { Age-equivalent }\end{array}$} & \multirow[t]{2}{*}{$\begin{array}{l}\text { Count to } \\
25 \text { in } \\
\text { Spanish }\end{array}$} \\
\hline & Spanish & English & & & Spanish & English & \\
\hline $\mathrm{M}$ & $2-11$ & 5-04 & & $\mathrm{D}$ & 6 & $7-03$ & \\
\hline $\mathrm{O}$ & 3-01 & $6-07$ & & $\mathrm{~J}$ & 6 & $5-05$ & \\
\hline $\mathrm{E}$ & $3-08$ & $5-06$ & & A & $6-01$ & $5-07$ & $X$ \\
\hline I & 4-02 & 6 & $X$ & B & $6-01$ & $6-02$ & \\
\hline
\end{tabular}




\begin{tabular}{|l|l|l|l|l|l|l|l|}
\hline U & $4-03$ & 6 & & L & $6-01$ & $5-09$ & X \\
\hline F & $5-01$ & $6-05$ & & S & $6-01$ & $4-05$ & X \\
\hline N & $5-02$ & $5-10$ & & R & $6-06$ & $4-09$ & \\
\hline Y & $5-05$ & $3-06$ & & K & $6-06$ & $4-07$ & \\
\hline C & $5-05$ & $5-11$ & $\mathrm{X}$ & P & $8-03$ & $5-1$ & $X$ \\
\hline
\end{tabular}

Table 4. Sample retellings of English subtraction problem.

\begin{tabular}{|l|l|l|l|l|l|}
\hline Child's & Retelling & \multicolumn{3}{|c|}{ Elements } \\
\cline { 3 - 6 } initial & & Numbers & Units & Action & Question \\
\hline $\mathrm{L}$ & $\begin{array}{l}\text { Sixteen people were going to see a panda, a panda. } \\
\text { And then seven went away. How many are there? }\end{array}$ & $\mathrm{I}$ & $\mathrm{I}$ & $\mathrm{C}$ & $\mathrm{C}$ \\
\hline $\mathrm{B}$ & $\begin{array}{l}\text { Seven people went *in the line*. Three people left. } \\
\text { Four people are waiting. }\end{array}$ & $\mathrm{D}$ & $\mathrm{I}$ & $\mathrm{I}$ & $\mathrm{M}$ \\
\hline $\mathrm{K}$ & $\begin{array}{l}\text { Sixteen people are waiting in line to see the giant } \\
\text { panda. Seven people got out. }\end{array}$ & $\mathrm{I}$ & $\mathrm{I}$ & $\mathrm{C}$ & $\mathrm{M}$ \\
\hline $\mathrm{R}$ & Sixteen people *waiting for to see* the big panda. & $\mathrm{M}$ & $\mathrm{I}$ & $\mathrm{M}$ & $\mathrm{M}$ \\
\hline
\end{tabular}

$\mathrm{I}=$ Identical, $\mathrm{C}=$ Consistent, $\mathrm{D}=$ Different, $\mathrm{M}=$ Missing. ${ }^{*}$ = grammar error

Table 5. Elements of Subtraction Problems included in retellings

\begin{tabular}{|l|l|l|l|l|}
\hline & \multicolumn{4}{|c|}{ English Subtraction Problem } \\
\hline & Identical & Consistent & Different & Missing \\
\hline Numbers & $59 \%$ & ---------- & $29 \%$ & $12 \%$ \\
\hline Units & $83 \%$ & $6 \%$ & $0 \%$ & $12 \%$ \\
\hline Action & $55 \%$ & $28 \%$ & $0 \%$ & $17 \%$ \\
\hline Question & $0 \%$ & $33 \%$ & $0 \%$ & $67 \%$ \\
\hline & \multicolumn{4}{|c|}{ Spanish Subtraction Problem } \\
\hline Numbers & $39 \%$ & -------- & $33 \%$ & $28 \%$ \\
\hline Units & $17 \%$ & $17 \%$ & $33 \%$ & $33 \%$ \\
\hline Action & $39 \%$ & $22 \%$ & $0 \%$ & $39 \%$ \\
\hline Question & $0 \%$ & $33 \%$ & $5 \%$ & $62 \%$ \\
\hline
\end{tabular}

Table 6. Sample Retellings of Spanish Subtraction Problem

\begin{tabular}{|l|l|l|l|l|l|}
\hline Child's & Retellings & \multicolumn{3}{|c|}{ Elements } \\
\cline { 3 - 6 } initial & & Numbers & Units & Action & Question \\
\hline $\mathrm{N}$ & $\begin{array}{l}\text { Catorce estaban descansando } \\
\text { Forteen were resting } \\
\text { y seis se metieron para dentro. } \\
\text { and six went into. }\end{array}$ & I & M & I & M \\
\hline $\mathrm{M}$ & $\begin{array}{l}\text { Había catorce "marinos" } \\
\text { There were forteen "sea animals" } \\
\text { y luego se metieron seis más } \\
\text { and then six more went in } \\
\text { y ícuántos "marinos" *ya está*? } \\
\text { and how many "sea animals" *already is*? }\end{array}$ & I & C & I & C \\
\hline U & $\begin{array}{l}\text { Estaba fifteen leones } \\
\text { There was fifteen lions } \\
\text { y six *se fue* para drink una agua para ellos }\end{array}$ & D & D & C & M \\
\hline
\end{tabular}




\begin{tabular}{|l|l|l|l|l|l|}
\hline Child's & Retellings & \multicolumn{3}{|c|}{ Elements } \\
\cline { 3 - 5 } initial & & Numbers & Units & Action & Question \\
\hline & $\begin{array}{l}\text { and } \underline{\text { six }} \text { *went [singular form] * to drink a water for } \\
\text { them } \\
\text { estaban descansando porque quieren agua, } \\
\text { they were resting because they want water, } \\
\text { los otros leones no, porque están dormidos. } \\
\text { the other lions no, because they are asleep. }\end{array}$ & & & & \\
\hline $\mathrm{F}$ & $\begin{array}{l}\text { Catorce leones estaban descansando } \\
\text { Forteen lions were resting } \\
\text { y diez estaban en la agua } \\
\text { and ten were in the water } \\
\text { ¿Cuántos *ya* están descansando? } \\
\text { How many are resting *already*? }\end{array}$ & $\mathrm{D}$ & $\mathrm{D}$ & $\mathrm{M}$ & $\mathrm{C}$ \\
\hline
\end{tabular}

I = Identical, $\mathrm{C}$ = Consistent, $\mathrm{D}=$ different, $\mathrm{M}$ = missing, * = grammar error. Texts in italics are translations of children's retellings. The underlined words were retold in English.

Table 7. Sample Retelling of the English Addition Problem

\begin{tabular}{|l|l|l|l|l|l|}
\hline \multirow{2}{*}{ Student } & \multirow{2}{*}{ Retelling } & \multicolumn{3}{|c|}{ Elements } \\
\cline { 3 - 6 } & O put five apples and eight pears. & Numbers & Units & Action & Question \\
\hline $\mathrm{L}$ & $\begin{array}{l}\text { There were a zoo guy and he gave to the monkeys, } \\
\text { bananas, and then at night he gave them bananas, oh } \\
\text { no, apples. }\end{array}$ & $\mathrm{M}$ & $\mathrm{C}$ & $\mathrm{I}$ & $\mathrm{M}$ \\
\hline $\mathrm{C}$ & $\begin{array}{l}\text { In the morning a zoo keeper gave eight pears to a } \\
\text { monkey. He gave some apples to the monkey. How } \\
\text { many pears and apples did the monkey have? }\end{array}$ & $\mathrm{M}$ & $\mathrm{I}$ & $\mathrm{I}$ & $\mathrm{C}$ \\
\hline $\mathrm{U}$ & $\begin{array}{l}\text { The man gave eighteen pums (sic) and they eat five } \\
\text { apples and they ... }\end{array}$ & $\mathrm{D}$ & $\mathrm{C}$ & $\mathrm{D}$ & $\mathrm{M}$ \\
\hline $\mathrm{A}$ & $\begin{array}{l}\text { There were six people *at line* to see the big } \\
\text { panda. Nine people left. How many *are people } \\
\text { left*? }\end{array}$ & $\mathrm{D}$ & $\mathrm{I}$ & $\mathrm{I}$ & $\mathrm{C}$ \\
\hline
\end{tabular}

I = Identical, C = Consistent, D = Different, $\mathrm{M}=$ Missing, * = grammar error.

Table 8. Elements of Addition Problems included in Retellings

\begin{tabular}{|l|l|l|l|l|}
\hline & \multicolumn{4}{|c|}{ English Problem } \\
\hline & Identical & Consistent & Different & Missing \\
\hline Numbers & $28 \%$ & - & $39 \%$ & $33 \%$ \\
\hline Units & $22 \%$ & $39 \%$ & 0 & $39 \%$ \\
\hline Action & $82 \%$ & $6 \%$ & $6 \%$ & $6 \%$ \\
\hline Question & 0 & $17 \%$ & $17 \%$ & $66 \%$ \\
\hline & \multicolumn{5}{|c|}{ Spanish Problem } \\
\hline Numbers & $39 \%$ & -------- & $28 \%$ & $33 \%$ \\
\hline Units & $6 \%$ & $67 \%$ & $6 \%$ & $22 \%$ \\
\hline Action & $67 \%$ & $22 \%$ & 0 & $11 \%$ \\
\hline Question & 0 & $33 \%$ & $11 \%$ & $56 \%$ \\
\hline
\end{tabular}

Table 9. Sample retelling of the Spanish Addition problem. 


\begin{tabular}{|c|c|c|c|c|c|}
\hline \multirow{2}{*}{$\begin{array}{l}\text { Child's } \\
\text { initial }\end{array}$} & \multirow[b]{2}{*}{ Retelling } & \multicolumn{4}{|c|}{ Elements } \\
\hline & & Numbers & Units & Action & Question \\
\hline K & $\begin{array}{l}\text { Margarita recogió nueve rosas. } \\
\text { Margarita collected nine roses. } \\
\text { Luego por la tarde recogió cinco margaritas. } \\
\text { Later in the afternoon she collected five daisies. } \\
\text { ¿Cuántos había *en todos*? } \\
\text { How many were there *in all*? }\end{array}$ & I & I & $\mathrm{C}$ & $\mathrm{C}$ \\
\hline M & $\begin{array}{l}\text { María fue al parque } \\
\text { Maria went to the park } \\
\text { a encontrar nueve margaritas, } \\
\text { to find nine daisies } \\
\text { luego ya se fue a su casa } \\
\text { and then she went to her house } \\
\text { y en su jardín había cinco más } \\
\text { and in her garden there were five more. } \\
\text { y ¿Cuántos *ya está*? } \\
\text { And how many *already is*? }\end{array}$ & I & $\mathrm{C}$ & $\mathrm{C}$ & $\mathrm{C}$ \\
\hline $\mathrm{J}$ & $\begin{array}{l}\text { Agarró five margaritas en la mañana. } \\
\text { She picked up five daisies in the morning. } \\
\text { Entonces ¿*Cuánto agarró flores y margaritas*? } \\
\text { Then *how much did she pick up flowers and } \\
\text { daisies*? }\end{array}$ & $\mathrm{M}$ & C & I & $\mathrm{C}$ \\
\hline $\mathrm{L}$ & $\begin{array}{l}\text { Ayer María agarró cinco flores } \\
\text { Yesterday Maria picked up five flowers } \\
\text { y luego ayer en la mañana agarró seis “marinos" } \\
\text { and then yesterday morning she picked up six "sea } \\
\text { animals” } \\
\text { ¿Cuántos quedan *más*? } \\
\text { How many are *left* there? }\end{array}$ & $\mathrm{D}$ & $\mathrm{D}$ & I & $\mathrm{D}$ \\
\hline
\end{tabular}

$\mathrm{I}$ = Identical, $\mathrm{C}=$ Consistent, $\mathrm{D}=$ different, $\mathrm{M}$ = missing, * = grammar error. Texts in italics are translations of children's retellings. The underlined words were retold in English.

Table 10. Examples of retellings for English Division Problem

\begin{tabular}{|l|l|l|l|l|l|l|}
\hline Child's & \multirow{2}{*}{ Retelling } & \multicolumn{5}{|c|}{ Elements } \\
\cline { 3 - 7 } & & Numbers & Units & Action & Condition & Question \\
\hline $\mathrm{R}$ & $\begin{array}{l}\text { There were twelve kids in the party. } \\
\text { They are sitting at the chair and eating } \\
\text { on the table. }\end{array}$ & $\mathrm{M}$ & $\mathrm{C}$ & $\mathrm{I}$ & $\mathrm{M}$ & $\mathrm{M}$ \\
\hline $\mathrm{O}$ & $\begin{array}{l}\text { Kids went to a party and each of them } \\
\text { *take* a table. }\end{array}$ & $\mathrm{M}$ & $\mathrm{C}$ & $\mathrm{C}$ & $\mathrm{M}$ & $\mathrm{M}$ \\
\hline $\mathrm{L}$ & $\begin{array}{l}\text { There were four children. There were } \\
\text { four tables. The number on the tables } \\
\text { was the same. How many are there in } \\
\text { all? }\end{array}$ & $\mathrm{D}$ & $\mathrm{I}$ & $\mathrm{D}$ & $\mathrm{M}$ & $\mathrm{D}$ \\
\hline $\mathrm{C}$ & $\begin{array}{l}\text { There were twelve children in each } \\
\text { table. How many children are there in } \\
\text { all? }\end{array}$ & $\mathrm{M}$ & $\mathrm{I}$ & $\mathrm{C}$ & $\mathrm{M}$ & $\mathrm{D}$ \\
\hline $\mathrm{F}$ & $\begin{array}{l}\text { Twelve children sat at four tables. } \\
\text { Each one of those tables had twelve }\end{array}$ & $\mathrm{I}$ & $\mathrm{I}$ & $\mathrm{I}$ & $\mathrm{M}$ & $\mathrm{C}$ \\
\hline
\end{tabular}




\begin{tabular}{|l|l|l|l|l|l|}
\hline & $\begin{array}{l}\text { children. How many children are at a } \\
\text { table? }\end{array}$ & & & & \\
\hline
\end{tabular}

$\mathrm{I}=$ Identical, $\mathrm{C}=$ Consistent, $\mathrm{D}=$ different, $\mathrm{M}=$ missing, * = grammar error.

Table 11. Elements of Division Problems included in retellings

\begin{tabular}{|l|l|l|l|l|}
\hline & \multicolumn{4}{|c|}{ English Problem } \\
\hline & Identical & Consistent & Different & Missing \\
\hline Numbers & $39 \%$ & ---------- & $11 \%$ & $50 \%$ \\
\hline Units & $56 \%$ & $28 \%$ & $6 \%$ & $11 \%$ \\
\hline Action & $56 \%$ & $17 \%$ & $5 \%$ & $22 \%$ \\
\hline Condition & $0 \%$ & ---------- & ----------- & $100 \%$ \\
\hline Question & $0 \%$ & $5 \%$ & $17 \%$ & $78 \%$ \\
\hline & \multicolumn{5}{|c|}{ Spanish Problem } \\
\hline Numbers & $67 \%$ & --------- & $5 \%$ & $28 \%$ \\
\hline Units & $72 \%$ & $0 \%$ & $0 \%$ & $28 \%$ \\
\hline Action & $72 \%$ & $0 \%$ & $11 \%$ & $17 \%$ \\
\hline Condition & $11 \%$ & ----------- & ---------- & $89 \%$ \\
\hline Question & $0 \%$ & $0 \%$ & $11 \%$ & $89 \%$ \\
\hline
\end{tabular}

Table 12. Examples of retellings for Spanish Division Problem

\begin{tabular}{|c|c|c|c|c|c|c|}
\hline \multirow{2}{*}{$\begin{array}{l}\text { Child's } \\
\text { initial }\end{array}$} & \multirow[t]{2}{*}{ Retellings } & \multicolumn{5}{|c|}{ Elements } \\
\hline & & Number & Units & Action & Condition & Question \\
\hline I & $\begin{array}{l}\text { Poner *todos de* fifteen pasteles } \\
\text { To put *all of* fifteen cakes } \\
\text { en tres cajas. } \\
\text { in three boxes. }\end{array}$ & I & I & I & $\mathrm{D}$ & $\mathrm{M}$ \\
\hline $\mathrm{M}$ & $\begin{array}{l}\text { Que una abuelita tenía quince pasteles } \\
\text { That a grandma had fifteen cakes } \\
\text { y luego puso uno en cada caja. } \\
\text { and then she put one in each box. }\end{array}$ & $\mathrm{D}$ & I & I & $\mathrm{D}$ & $\mathrm{M}$ \\
\hline $\mathrm{Y}$ & $\begin{array}{l}\text { Tenía una señora quince cakes } \\
\text { A lady had fifteen cakes } \\
\text { y entonces puso the number in each cake } \\
\text { and then she put the number in each cake } \\
\text { y entonces tenía, } \\
\text { and then she had, } \\
\text { se fue en bici para darle los pasteles a } \\
\text { somebody. } \\
\text { she went on a bike to give the cakes to } \\
\text { somebody }\end{array}$ & $\mathrm{M}$ & $\mathrm{M}$ & I & $\mathrm{M}$ & $\mathrm{M}$ \\
\hline $\mathrm{J}$ & $\begin{array}{l}\text { La señora Gómez tenía fifteen cakes } \\
\text { Mrs. Gomez had fifteen cakes } \\
\text { Puso three en *las box*. } \\
\text { she put three in *the boxs*. }\end{array}$ & I & I & I & $\mathrm{D}$ & $\mathrm{M}$ \\
\hline
\end{tabular}

$\mathrm{I}=$ Identical, $\mathrm{C}=$ Consistent, $\mathrm{D}=$ different, $\mathrm{M}=$ missing, * = grammar error. Texts in italics are translations of children's retellings. The underlined words were retold in English. 